\title{
Electrolytic Removal of Cadmium, Lead and Copper from Wastewater
}

\author{
Isaque C. A. Santos, Isabela O. Santos, Leandro V. Pontual, Luciane P. C. Monteiro, \\ Fernando B. Mainier* \\ Escola de Engenharia, Universidade Federal Fluminense, Niterói, Brazil \\ Email: *fmainier@uol.com.br
}

Received 11 March 2016; accepted 15 April 2016; published 18 April 2016

Copyright (C) 2016 by authors and Scientific Research Publishing Inc.

This work is licensed under the Creative Commons Attribution International License (CC BY). http://creativecommons.org/licenses/by/4.0/

(c) (i) Open Access

\begin{abstract}
The respective compounds of copper, cadmium and lead, owing to their strong toxic potential, as a result of industrial effluent, have left a trail of contamination in humans and the environment. This paper aimed to study the electrode position on the removal of aqueous solutions of cadmium, lead and copper, using an electrolytic cell with a metallic screen cathode of carbon steel and platinum anode. Removal efficiencies were obtained by analysis of the solutions before and after treatment, using the methodology of cathodic-stripping voltammetry with a mercury drop electrode to quantify the concentrations of $\mathrm{Cd}^{2+}, \mathrm{Pb}^{2+}$ and $\mathrm{Cu}^{2+}$. Removal efficiencies were obtained of $\mathbf{9 4 . 0 7 \%}$ for cadmium, $\mathbf{9 4 . 7 1 \%}$ for lead and $\mathbf{9 6 . 1 9 \%}$ for copper, demonstrating that electrolytic removal is an effective technique for the removal of these metals from simulated industrial wastewater.
\end{abstract}

\section{Keywords}

Copper, Lead, Cadmium, Electrolytic Removal, Effluents, Contaminations

\section{Introduction}

Toxic metals such as lead, copper and cadmium and their respective salts have been used in several industrial segments and, consequently, have led to a series of large-scale environmental contamination in the modern world. Owing to its toxicity and bio-accumulation these have caused illness for workers in these industrial segments. Some diseases, such as lead poisoning (saturnism) is associated with contamination by lead [1]-[4], copper is associated with Wilson's disease [5]-[7], while cadmium focuses on the bones and causes "itai-itai" disease, so-called after the contamination that occurred in Japan in early 1970 [8]-[10].

${ }^{*}$ Corresponding author.

How to cite this paper: Santos, I.C.A., Santos, I.O., Pontual, L.V., Monteiro, L.P.C. and Mainier, F.B. (2016) Electrolytic Removal of Cadmium, Lead and Copper from Wastewater. Journal of Environmental Protection, 7, 699-704.

http://dx.doi.org/10.4236/jep.2016.75062 
Cadmium is a grey metal with a metallic shine, is soft, ductile and malleable, whose surface darkens when in contact with the air owing to the formation of an oxide layer. It is a rare element and its concentration in the earth's crust is of the order of $0.1-0.5 \mathrm{~g} / \mathrm{kg}$, and is normally associated with the ores of zinc, lead and copper. Cadmium is used primarily in rechargeable batteries, pigments, in the stabilizers for PVC, metal coatings and in certain alloys or compounds [8] [11].

More than $70 \%$ of lead is used in the manufacture of lead batteries, owing to their low price, high reliability and good performance. The remainder is used in the manufacture of alloys, insulators for X-rays, ammunition and lead salts. Effluents of these industries can affect the environment and workers dramatically. The possibility of exposure to lead can cause adverse effects on various parts of the human body. The parts most affected are the brain and the entire nervous system, kidneys, blood and the male reproductive system. Relatively low levels of pellets can affect a developing fetus and young children, impairing their mental development [12] [13].

Copper can be considered as one of the earliest metals known to man where its applications has been present in various social and industrial areas, and its technologies involve, directly or indirectly, living beings and the environment. Copper is found naturally in rocks, soil, water, sediments and, at lower levels, in the air, and its average concentration in the earth's crust is about $50 \mathrm{~g} / \mathrm{kg}$. World copper production exceeds 23 million tons/ year, with a large part of the copper produced from sulfide minerals found in deep deposits. However, the metallic waste from copper and its alloys from target industries, consumer electronics and solid waste (or electronic rubbish) from electrical and electronic equipment have contributed to more than $35 \%$ of the production end of copper [14].

In Brazil this is already an issue for waste disposal and the standard for cadmium, lead and copper in effluent discharge is set by the CONAMA resolution 430/2011 [15], which sets the maximum allowed value at $0.2 \mathrm{mg}$ $\mathrm{Cd}^{2+} / \mathrm{L} ; 0.5 \mathrm{mg} \mathrm{Pb}^{2+} / \mathrm{L}$ and $1.0 \mathrm{mg} \mathrm{Cu}^{2+} / \mathrm{L}$, respectively. Owing to the high toxicity of cadmium, lead and copper, along with their widespread use in industry, specific treatments for the removal of these elements from waste should be studied. Research should be conducted to develop new methods of metal removal or to improve existing methods.

In addition to warning the population about the evils caused by these toxic metals, this study aims to demonstrate a simple electrolytic treatment capable of removing these ions from industrial effluents efficiently, while causing minimal impact to the environment.

\section{Materials and Methods}

An electrochemical cell is the basis of the process, consisting of a cathode and an anode immersed in a solution, as shown in Figure 1. When a current is applied to the cell by a rectifier, the metals will be deposited on the cathode, thereby obtaining the separation. The electrochemical recovery of metals basically involves two steps:

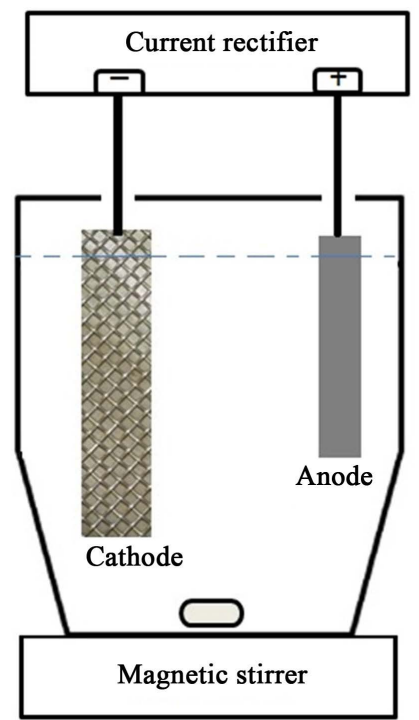

Figure 1. Schematic assembly of removal process. 
electrode position of the metal, followed by some form of stripping to remove the metal from the cathode. This stripping process can be accomplished by chemical or electrochemical dissolution, by electrolysis quarrying or reversing the polarity of the electrode.

Solutions were prepared initially containing cadmium, lead and copper ions, respectively, based on soluble salts. These simulations were used as effluent. The salt used was cadmium acetate dihydrate, lead acetate trihydrate and anhydrous copper sulfate. The concentrations used were 100, 150 and $200 \mathrm{mg} / \mathrm{L}$ for each ion.

In the experiments an electrolytic cell was used, made up of an acrylic container with a maximum capacity of $500 \mathrm{~mL}$, and containing the anode (positive pole) and the cathode (negative pole) connected to a power supply of dimmable direct current (current rectifier), with a voltage of $20-30 \mathrm{~V}$. The continuous agitation of the solution was done with a magnetic stirrer. The temperature was set at $25^{\circ} \mathrm{C}$.

The anode was made up of a thin plate of platinum, with a total area of $4.2 \mathrm{~cm}^{2}$. For the cathode, a rectangular screen of carbon steel $(6.5 \mathrm{~cm} \times 4.0 \mathrm{~cm})$ was used, with a wire diameter of $0.30 \mathrm{~mm}$ and a mesh opening of 0.55 $\mathrm{mm}$. Each screen had 47 wires of $6.5 \mathrm{~cm}$ and 77 wires of $4 \mathrm{~cm}$, with a total area of $57.82 \mathrm{~cm}^{2}$. The carbon steel screen is shown in Figure 2.

Some operational conditions, such as the time and current/voltage for this experiment, were based on Faraday's law (Equation (1)). This equation requires that: a) the amount of substance deposited is directly proportional to the amount of electricity passed through the electrolytic solution; and b) the quantities of different substances are deposited in proportion to their electrochemical equivalents. Thus, using Equation (1) [16] [17], it is possible estimate the time required to deposit the metal on the carbon steel cathode.

$$
M=Z \cdot i \cdot t
$$

where:

$m=$ mass, g;

$Z=$ electrochemical equivalent (g/coulomb);

$i=$ current, $\mathrm{A}$;

$t=$ time, $\mathrm{h}$.

Using this equation for copper, lead and cadmium ions, it is possible to calculate the theoretical amount of metal that can be deposited on the cathode in an experiment. As the intention was to remove all of these ions from the various solutions in this way, under predetermined conditions of operation, it is possible choose the variable of interest over time.

After preforming the removal experiments, the residual concentrations of $\mathrm{Cd}^{2+}, \mathrm{Cu}^{2+}$ and $\mathrm{Pb}^{2+}$ ions in each sample were checked using a voltammetric analyzer (VA 767 Metrohm Computrace). This equipment works with three electrodes combined: the working electrode (mercury multimode), reference electrode (Ag/AgCl-KCl $3.0 \mathrm{~mole} / \mathrm{L}$ ) and auxiliary platinum electrode. The removal efficiencies and average velocity removal were then calculated using Equation (2) and Equation (3), respectively,

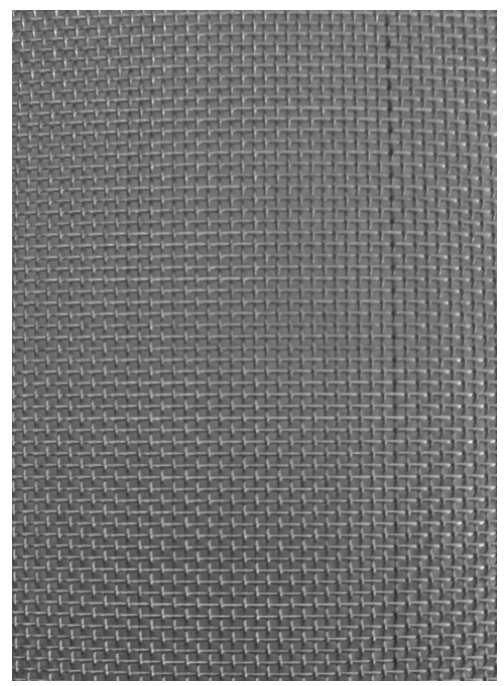

Figure 2. Carbon steel screen used as cathode. 


$$
\begin{gathered}
E_{\text {effic }}=\left(C_{\text {init }}-C_{\text {final }} / C_{\text {init }}\right) 100 \\
v=C_{\text {init }}-C_{\text {final }} / t
\end{gathered}
$$

where:

$E_{\text {effic }}=$ efficiency of removal (\%);

$v=$ Average velocity removal $(\mathrm{mg} / \mathrm{L} \cdot \mathrm{min})$;

$C_{\text {init }}=$ concentration of solution before the electrochemical removal process;

$C_{\text {final }}=$ concentration of the solution after the electrochemical removal process;

$t=$ temp of removal of contaminant.

\section{Results and Discussion}

All experiments were repeated three times, and the results of such tests are presented on the basis of the arithmetic average.

The graph in Figure 3 shows the removal efficiency (\%) applied to the $\mathrm{Cu}^{2+}, \mathrm{Cd}^{2+}$ and $\mathrm{Pb}^{2+}$ ions in the initial concentrations of 100,150 and $200 \mathrm{mg} / \mathrm{L}$, using a voltage of $20 \mathrm{~V}$ and a current of $0.2 \mathrm{~A}$.

For cadmium, removal efficiencies (\%) decreased with the increase in initial concentrations. For lead removal, efficiency was practically constant. However, for copper, there was a significant increase in removal efficiencies with increasing initial concentration.

The graph in Figure 4 shows the variation of removal efficiency for the three ions, depending on the theoretical times of deposition based on Faraday's equation (Equation (1)). In this experiment the concentration of 100 $\mathrm{mg} / \mathrm{L}$ for the $\mathrm{Cu}^{2+}, \mathrm{Cd}^{2+}$ and $\mathrm{Pb}^{2+}$ ions was fixed using a fixed voltage of $20 \mathrm{~V}$ and a current of $0.2 \mathrm{~A}$. In the graph " $\mathrm{t}$ " is the theoretical value, while " $\mathrm{t}_{1}$ " and " $\mathrm{t}_{2}$ " are an increase in the time of $25 \%$ and $50 \%$ for each metal, respectively, represented by " $\mathrm{t}_{1}=1.25 \mathrm{t}$ " and " $\mathrm{t}_{2}=1.5 \mathrm{t}$ ".

The results show that the increase in deposition time favors the greatest removal with values greater than $90 \%$. In these trials removal efficiencies of $94.07 \%$ for cadmium, $94.71 \%$ for lead and $96.19 \%$ for copper were obtained. For copper and cadmium increased time favored a higher percentage yield, but for lead there was a significant gain.

The graph in Figure 5 shows the variation of average velocity of removal of the three ions, fixing the concentration in $100 \mathrm{mg} / \mathrm{L}$ to the $\mathrm{Cu}^{2+}, \mathrm{Cd}^{2+}$ and $\mathrm{Pb}^{2+}$ ions and using a voltage of 20,25 e $30 \mathrm{~V}$. It was observed that the increase in voltage favors an increase in the deposition velocity of copper and cadmium. However, for the lead this remains almost constant. Probably this fact is a result of the conditioning properties of lead in relation to conductivity and the highest evolution of hydrogen [14] [15].

Another issue that must be stressed is the evolution of hydrogen during the process. This was constant and probably decisive in decreasing the efficiency. Agitation was applied to minimize the consequences of this evolution.

\section{Conclusions}

Based on the literature and laboratory tests, the following conclusions are made:

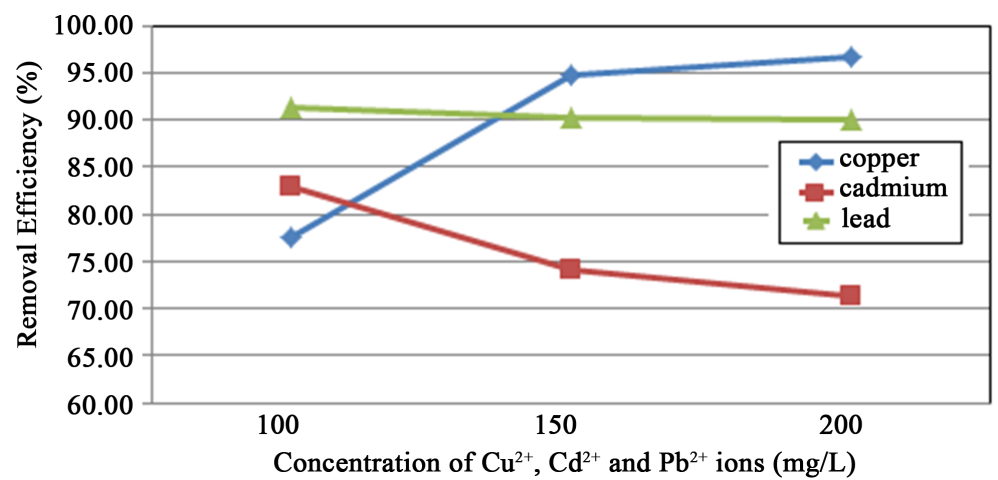

Figure 3. Removal efficiency (\%) applied to the $\mathrm{Cu}^{2+}, \mathrm{Cd}^{2+}$ and $\mathrm{Pb}^{2+}$ ions at $20 \mathrm{~V}$ and $0.2 \mathrm{~A}$. 


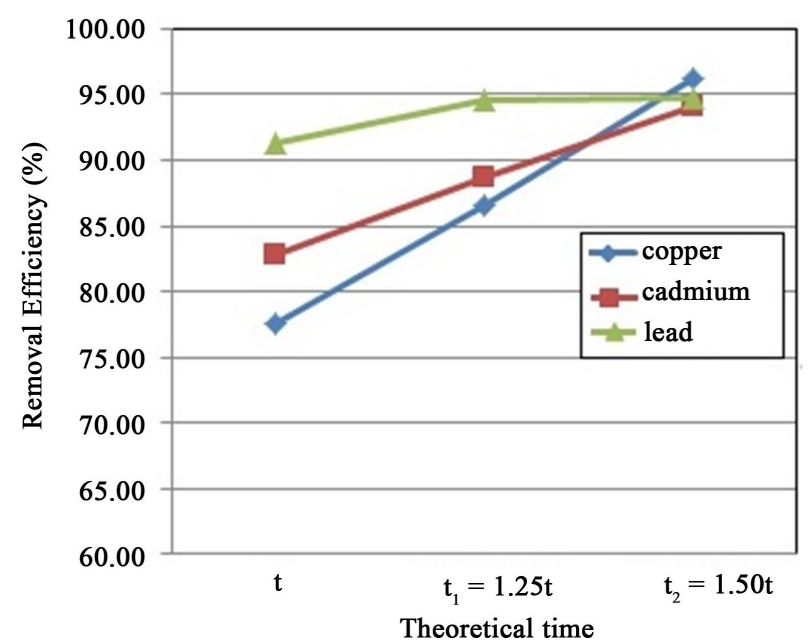

Figure 4. Variation of removal efficiency (\%) of three ions depending on the theoretical times of deposition at $20 \mathrm{~V}$ and $0.2 \mathrm{~A}$.

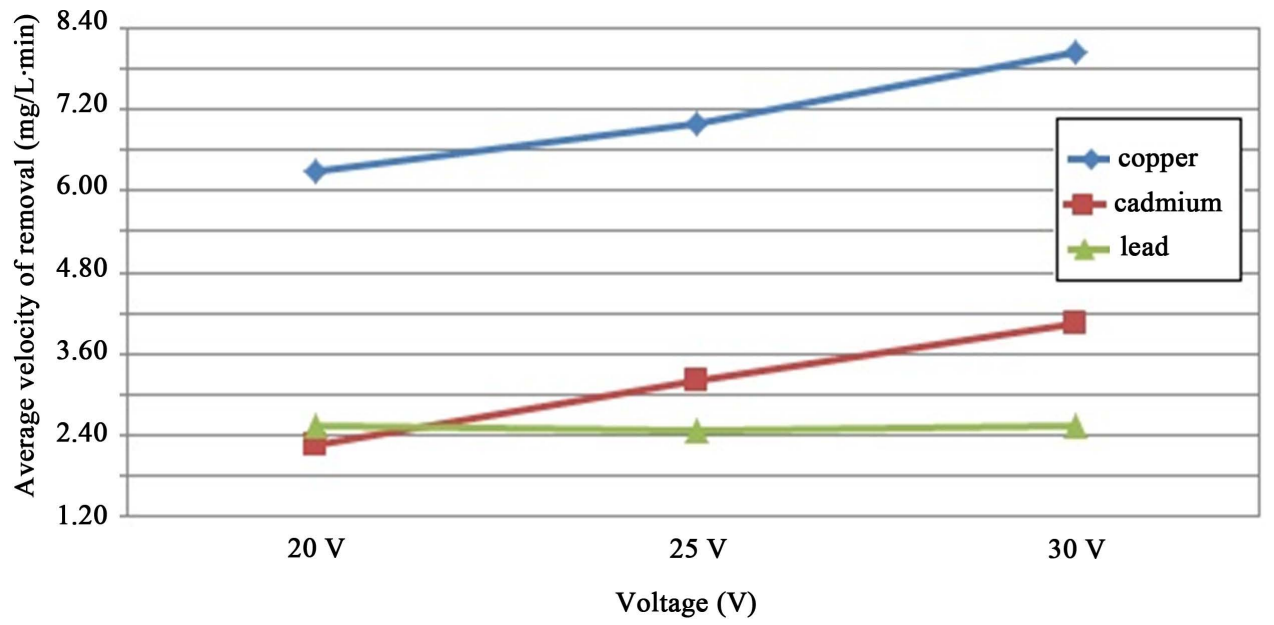

Figure 5. Variation of average velocity of removal of $\mathrm{Cu}^{2+}, \mathrm{Pb}^{2+}$ and $\mathrm{Cd}^{2+}$ ions in concentration of $100 \mathrm{mg} / \mathrm{L}$.

Electrochemistry is an effective technique for removing these metals from waste water, as its main advantages compared to conventional processes means that there is no need for chemical product input and sludge generation.

The increased reaction time resulted in an increase in the removal efficiencies, with the largest removals observed at $50 \%$ greater reaction times than theoretical times $\left(t_{2}=1.5 t\right)$. In these experiments removal efficiencies of $94.07 \%$ for cadmium, $94.71 \%$ for lead and $96.19 \%$ for copper were obtained

\section{References}

[1] Verheij, J., Voortman, J., van Nieuwkerk, C.M., Jarbandhan, S.V., Mulder, C.J. and Bloemena, E. (2009) Hepatic Morphopathologic Findings of Lead Poisoning in a Drug Addict: A Case Report. Journal of Gastrointestinal and Liver Diseases, 18, 225-227.

[2] Minozzo, R., Wagner, S.C., Santos, C.H., Deimling, L.I. and Mello, R.S. (2009) Prevalência de anemia emtrabalhadoresexpostosocupacionalmenteaochumbo (Prevalence of Anemia in Workers with Work-Related Exposure to Lead). Revista Brasileira de Hematologia e Hemoterapia, 31, 94-97. (In Portuguese) http://dx.doi.org/10.1590/S1516-84842009005000018

[3] Sharma, R., Ramteke, S., Patel, K.S., Kumar, S., Sarangi, B., Agrawal, S.G. and Milosh, H. (2015) Contamination of Lead and Mercury in Coal Basin of India. Journal of Environmental Protection, 6, 1430-1441 http://dx.doi.org/10.4236/jep.2015.612124 
[4] Aissi, A.K., Pazou, E.Y., Ahoyo, T.A., Fah, L., Fanou, B., Koumolou, L. and Edorh, P.A. (2014) Evaluation of Toxicological Risk Related to Presence of Lead and Cadmium in Moringaoleifera Lam. Leaves Powders Marketed in Cotonou (Benin). Food and Nutrition Sciences, 5, 770-778. http://dx.doi.org/10.4236/fns.2014.59087

[5] Ala, A., Borjigin, J., Rochwarger, A. and Schilsky, M. (2005) Wilson Disease in Septuagenarian Siblings: Raising the Bar for Diagnosis. Hepatology, 41, 668-670. http://dx.doi.org/10.1002/hep.20601

[6] Ala, A., Walker, A.P., Ashkan, K., Dooley, J.S. and Schilsky, M.L. (2007) Wilson's Disease. The Lancet, 369, $397-408$. http://dx.doi.org/10.1016/S0140-6736(07)60196-2

[7] Ferenci, P., et al. (2005) Diagnostic Value of Quantitative Hepatic Copper Determination in Patients with Wilson's Disease. Clinical Gastroenterology and Hepatology, 3, 811-818. http://dx.doi.org/10.1016/S1542-3565(05)00181-3

[8] Mainier, F.B., Fernandes, L.H. and Monteiro, L.P.C. (2014) Toxicity of Cadmium and Electrolytic Removal Process, Journal of Environmental Science and Water Resources, 3, 118-121.

[9] Fernandes, L.H. and Mainier, F.B. (2014) Os Riscos da Exposição Ocupacional ao Cádmio (The Risks of Occupational Exposure to Cadmium). Sistemas \& Gestão, 9, 194-199. (In Portuguese)

[10] Nordberg, G.F. (2009) Historical Perspectives on Cadmium Toxicology. Toxicology and Applied Pharmacology, 238, 192-200. http://dx.doi.org/10.1016/j.taap.2009.03.015

[11] Mainier, F.B., Monteiro, L.P.C., Fernandes, L.H. and Oliveira, M.A. (2011) Restrictions on the Use of Cadmium Coating in Industries. Journal of Science and Technology, 3, 176-180.

[12] Clark, L.G., de Oliveira, H.G. and Clark, O.A. (2010) A exposição ocupacional ao chumbo e os riscos à saúde do trabalhador (Lead occupational exposure and health risks to worker). Jornal Brasileiro de Economia da Saúde, 2, 8-14. (In Portuguese)

[13] Doumouchtsis, K.K., Doumouchtsis, S.K., Doumouchtsis, E.K. and Perrea, D.N. (2009) The Effect of Lead Intoxication on Endocrine Functions. Journal of Endocrinological Investigation, 32, 175-183. http://dx.doi.org/10.1007/BF03345710

[14] ICGS (International Copper Study Group) (2015) The World Copper Fact Book 2015. http://www.icsg.org

[15] CONAMA (Conselho Nacional doMeioAmbiente) (2009) Resolução No 420 (National Council for the Environment. Resolution No. 420). 81-84. (In Portuguese)

[16] Allen, J.B. and Larry, R.F. (2001) Electrochemical Methods: Fundamentals and Applications. John Wiley, Hoboken.

[17] Bagotsky, V.S. (Ed.) (2006) Fundamentals of Electrochemistry, Vol. 44. John Wiley, Hoboken. 